\title{
MODERN UKRAINE THROUGH CROSS-BORDER POPULATION FLOWS
}

\author{
Gennady BALABANOV \\ National Aviation University, Kyiv, Ukraine \\ gennady@balabanov.kiev.ua
}

\begin{abstract}
The article defines the specialty of both broad and specific migration interpretation as a human geographic mobility and justifies the actuality of cross-border population flow problems for the modern Ukraine. Object of the research are the data about the flow of foreigners and Ukrainian citizens through the Ukrainian national borders. Elicited the specifics of agency-level State border guard service of Ukraine statistics, justified the procedure of forming the information base of the study. The scale, reasons and dynamics for the entry and exit population flows through the Ukrainian national borders are estimated. Special attention is paid to the flows' geographical structure analysis. The roles of specific border parts in the flows of migrants are defined. The author outlines further research perspectives.
\end{abstract}

Key words: Ukraine, cross-border population flows, geographical structure of the cross-border population flows

UDC: $911.3: 314$

\section{СУЧАСНА УКРАЇНА КРІЗЬ ПРИЗМУ ТРАНСКОРДОННИХ ПОТОКІВ НАСЕЛЕННЯ}

\author{
Геннадій БАЛАБАНОВ \\ Національний авіаційний університет, Київ, Україна \\ gennady@balabanov.kiev.ua
}

\begin{abstract}
Анотація: Розкрито особливості вузького і широкого трактування міграції як просторової мобільності населення. Обґрунтовано актуальність проблем транскордонного руху населення для сучасної України. Об'єктом дослідження є потоки іноземних громадян і громадян України через державний кордон України. Виявлено особливості відомчої статистики Державної прикордонної служби України, обгрунтовано порядок формування інформаційної бази дослідження. Наведено оцінку масштабів, причин і динаміки розвитку в'їзного та виїзного потоків населення через державний кордон України. Особливу увагу приділено аналізу географічної структури транскордонних потоків населення. Визначено роль окремих ділянок державного кордону в забезпеченні руху міжнародних мігрантів. Окреслено перспективи подальших досліджень.
\end{abstract}

Ключові слова: Україна, потоки населення через державний кордон, географічна структура транскордонних потоків населення

Удк: $911.3: 314$

Вступ. Постановка проблеми. Вибір суверенною Україною стратегічних пріоритетів розвитку, глибоке реформування всіх сфер суспільного життя заради поступального економічного зростання, соціального прогресу i забезпечення стійкості природних комплексів відбуваються у складних умовах глобалізації, посилення взаємозалежності i протиріч між країнами світу. Глобалізація супроводжується інтенсифікацією міждержавних політичних зв'язків, потоків товарів і послуг, капіталу, людей та інформації. Зокрема, технологічний прогрес на транспорті i в галузі телекомунікацій створив сприятливі передумови для динамічного зростання масштабів транскордонних потоків населення. Ускладнюється географічна картина територіальних переміщень людей між континентами, регіонами і державами світу.

Сальдо зовнішніх міграцій варто розглядати як чутливий індикатор рівня політичної стабільності, безпеки i демократичності держави, успішності

(C) Г. Балабанов курсу соціально-економічного розвитку, рівня зайнятості, оплати праці і доходів громадян, стану охорони здоров'я, розвитку освіти і культури, сприятливості природних та інфраструктурних умов для проживання та відпочинку тощо. Міжнародна міграція зазнає більшого впливу політико-правових механізмів регулювання, ніж внутрішня.

Глобалізація відкриває для кожної країни нові потенційні можливості, хоча водночас існують i серйозні загрози. В перші роки незалежності України зовнішні міграційні потоки мали здебільшого етнічні мотиви. Пізніше на перший план вийшли економічні причини міграції внаслідок падіння рівня життя населення, безробіття, корупції, проблем 3 реалізацією творчого потенціалу професійно підготовлених кадрів тощо. Сучасна Україна зіштовхнулася 3 новими безпрецедентними викликами геополітичного, військового та соціальноекономічного характеру, що призвело до появи потужних потоків вимушених мігрантів.

Важлива роль міграційних процесів для життєдіяльності українського суспільства обумови- 
ла створення нормативно-правової бази регулювання міграції. В 1991 р. було прийнято Закон України «Про державний кордон України», 1994 р. - «Про порядок виїзду з України і в’їзду в Україну громадян України», 2001 р. - «Про імміграцію», 2003 р. «Про свободу пересування та вільний вибір місця проживання в Україні», 2011 р. - «Про біженців та осіб, які потребують додаткового або тимчасового захисту», «Про правовий статус іноземців та осіб без громадянства» та ін. У 2002 р. Україна приєдналася до Конвенції 1951 р. про статус біженців та Протоколу щодо статусу біженців 1967 р.; Верховна Рада України ратифікувала угоду про офіційне членство України у Міжнародній організації з міграції (МОМ). У 2010 р. було створено Державну міграційну службу України, наступного року схвалено Концепцію державної міграційної політики.

Разом 3 тим чимало гострих проблем науковопрактичного характеру залишаються невирішеними. Зокрема, зростає актуальність оцінки місця України в системі координат транскордонного руху населення 3 позицій широкого тлумачення міжнародної міграції (безвідносно до тривалості подорожі). Все більше підстав вважати завузьким розуміння органами статистики України міжнародного мігранта як фізичної особи, котра перетинає державний кордон на виїзд/в'їзд на строк понад 6 місяців згідно талонів офіційної реєстрації. Такий підхід здатен виявити лише «верхівку айсбергу» масштабних просторових переміщень населення через державні кордони.

Аналіз останніх досліджень і публікацій. Теоретичні засади дослідження міграцій населення сформовані зусиллями представників різних галузей знань (демографів, географів, соціологів, економістів, політологів, істориків та ін.), що дозволяє висвітлити різні змістовні аспекти цього складного феномену. Вагомим внеском у створення наукової картини міграційних процесів є праці Жанни Зайончковської, Джорджа Зіпфа, Володимира Іонцева, Стефена Кастлса і Марка Міллера, Еверетта Лі, Олени Малиновської, Дугласа Массея, Віктора Переведенцева, Олексія Позняка, Ірини Прибиткової, Ернста Равенштайна, Леоніда Рибаковського, Юрія Римаренка, Олександра Хомри, Тетяни Юдиної та ін.

За останнє десятиріччя з'явилися важливі публікації методологічного характеру, підготовлені ООН та ЄC [17], [20], [7], [6], [16].

Проблематика міжнародної міграції в контексті розвитку України була предметом розгляду у багатьох наукових працях. Увага дослідників зосереджена перш за все на питаннях трудової міграції [23], [5], [15], [18]; тенденціях розвитку міграційних зв'язків з країнами СС [23], [8], [14], [15] і Російською Федерацією [21], [4], [3]; малому прикордонному русі населення [15]; впливі міжнародної міграції на етнічну структуру населення України [9] та ін. Опубліковані змістовні аналітичні огляди, підготовлені Представництвом Міжнародної організації 3 міграції в Україні, Національним інститутом стратегічних досліджень при Президентові України [10], Державною міграційною службою України [12]. Разом 3 тим актуальні проблеми динаміки i геопросторової структури руху населення через державний кордон України висвітлені недостатньо.

Формулювання цілей статті. Постановка завдання. Метою статті $є$ виявлення масштабів, тенденцій розвитку і геопросторової структури руху населення через державний кордон України на засадах широкого трактування міграції як просторової мобільності населення (Human Geographic Mobility).

Мета роботи обумовила необхідність вирішення таких основних завдань.

1. Обгрунтувати методологічні засади та особливості інформаційної бази дослідження.

2. Виявити тенденції змін обсягів і географічну структуру потоків населення через державний кордон України.

3. Оцінити роль окремих ділянок державного кордону України в забезпеченні руху міжнародних мігрантів.

Виклад основного матеріалу.

1. Наявність вузького i широкого розуміння базової категорії «міграція населення» зумовлює необхідність стисло розкрити суть обох підходів стосовно зовнішньої міграції. Спочатку зупинимось на вузькому підході. «Рекомендації зі статистики міжнародної міграції», підготовлені ООН у 1998 р., містять наступні визначення:

«Довгостроковий мігрант. Особа, яка прибуває до країни, що не $є$ країною його/їі звичного проживання, на строк не менше одного року (12 місяців), у результаті чого країна призначення фактично стає країною його/її звичного проживання. 3 точки зору країни вибуття така особа буде вважатися довгостроковим емігрантом, а 3 точки зору країни прибуття така особа буде вважатися довгостроковим іммігрантом.

Короткостроковий мігрант. Особа, яка прибуває до країни, що не є країною його/їі звичного проживання, на строк щонайменше 3 місяці, але менше одного року (12 місяців), за виключенням випадків прибуття до цієї країни з метою відпочинку, проведення відпустки, відвідування друзів або родичів, по справах, для лікування або релігійного паломництва» $[17$, с. 15 ].

Наведені визначення явно спрямовані на розмежування 3 терміном «іноземний турист», про що вже йшлося у публікаціях автора [1]. Отже, всі інші особи окрім довгострокових і короткострокових мігрантів не вважаються мігрантами і зазвичай не враховуються статистикою міжнародної міграції. По відношенню до них у Рекомендаціях ООН 1998 р. вживаються терміни «міжнародно-мобільні особи», «відвідувачі», «подорожуючі» [17, с. 40], а розробник Практичного посібника зі статистики міжнародної міграції для країн Східної Свропи і Центральної Азії О. Чудиновських використовує термін «візитери» [7, c. 18]. Регламент ЄС у сфері міграційної статистики 2007 р. теж передбачає в якості основного індикатора для визначення міжнародної міграції факт прибуття/ вибуття особи на строк понад 12 місяців [16].

По-перше, відразу виникає методологічна проблема невідповідності вітчизняної міграційної 
статистики міжнародним рекомендаціям, тому що в Україні мігранта визначають за талонами реєстрації/ зняття з реєстрації місця проживання, якщо особа прибула чи вибула на строк понад 6 місяців. По-друге, частина громадян уникає офіційної реєстрації факту зміни місця проживання. За методологією Держстату України, в 2013 р. кількість міжнародних мігрантів, прибулих до України, становила 54,1 тис. осіб, а вибулих - 22,2 тис. осіб. Міграційний приріст склав 31,9 тис. осіб [13, с. 282-284]. Причому додатне сальдо зовнішніх міграцій стабільно фіксується з 2005 р. Варто погодитись 3 висновком О. Малиновської: «...насправді країна продовжує втрачати населення в результаті міграції, а додатне сальдо за поточним обліком переміщень пояснюється лише тим, що прибуття населення завжди реєструється краще, ніж вибуття» [10].

Тепер про широкий концептуальний підхід до тлумачення міграції. Публікація Міжнародної організації з міграції «Право міжнародної міграції: Глосарій термінології в галузі міграції» містить наступну дефініцію: «Міграція - процес переміщення населення через міжнародний кордон або в межах держави. Міграція охоплює будь-який вид переміщень незалежно від їх тривалості, складу чи причин; вона включає пересування біженців, переміщених осіб, виселених людей та економічних мігрантів» [6, с. 41]. За Л. Рибаковським, міграцією в широкому розумінні цього слова $\epsilon$ процес територіального переміщення населення незалежно від тривалості, регулярності і цільової спрямованості [19].
Виходячи 3 мети даної роботи, об'єктом дослідження $€$ потоки громадян України та іноземних громадян через державний кордон України. Рух населення реалізується шляхом автомобільного, залізничного, морського, поромного, річкового, повітряного та пішохідного сполучення через спеціальні пункти пропуску. Здійснення в установленому порядку прикордонного контролю i пропуску через державний кордон України осіб, транспортних засобів, вантажів та іншого майна, а також виявлення і припинення випадків незаконного ïx переміщення $€$ одним 3 основних завдань Державної прикордонної служби України (ДПСУ). Тому головним джерелом інформації було обрано статистику зазначеного відомства.

Всі офіційні публікації Держстату України про потоки людей через державний кордон готуються за даними Адміністрації ДПСУ. Звітна інформація про пропуск осіб та транспортних засобів через державний кордон України збирається за формами 1-ДПСУ, 2-ДПСУ, 3-ДПСУ, погодженими Держстатом України (інструкції щодо заповнення форм затверджені наказом від 18.05.2006 №363). Перевагою зазначеної статистики є можливість будувати динамічні ряди спостережень на єдиній методологічній основі. Коректне сприйняття наведеної тут і далі інформації можливе лише за умови врахування кількох важливих застережень:

- дані ДПСУ лише умовно можуть вважатися статистикою транскордонних потоків населення, тому що обліковуються факти перетину кордону, а не кількість фізичних осіб. Наприклад, одна фізична

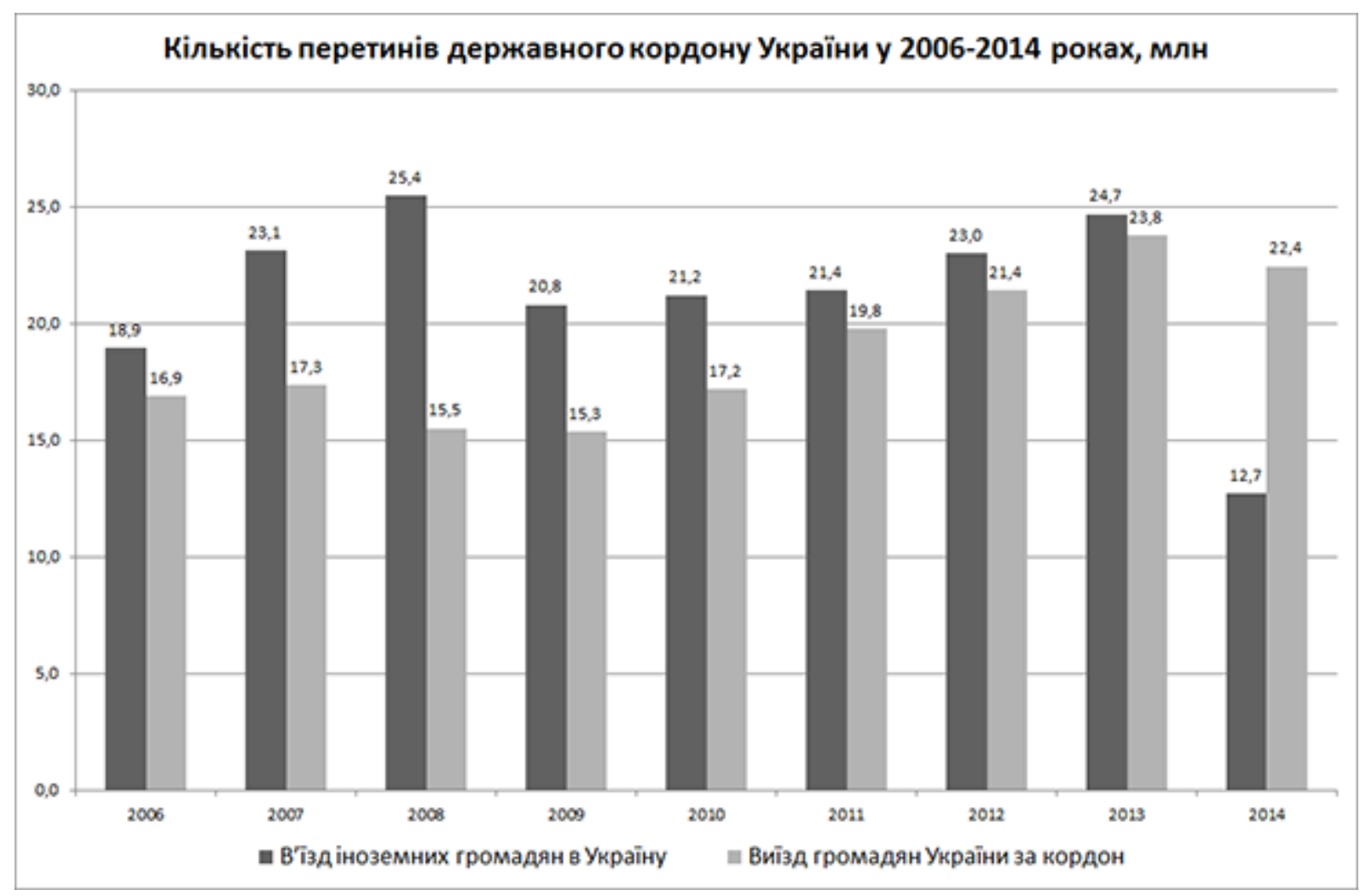

Рис. 1. Кількість перетинів державного кордону України у 2006-2014 роках, млн. Побудовано за даними Держприкордонслужби України [24; 25]. Іноземні громадяни - без обслуговуючого персоналутранспортних засобів та транзиту. Громадяни України - без обслуговуючого персоналу транспортних засобів та військовослужбовців. 
особа може перетинати кордон кілька разів на рік;

- під час контролю i пропуску в Україну іноземного громадянина фіксується країна, з якої він прибув, але не громадянство цієї особи. Наприклад, іноземець прибув до України з Польщі, проте він може бути громадянином Німеччини;

- під час контролю i виїзду громадянина України за кордон вказується країна, до якої особа прямує. Втім не обов'язково це буде країна кінцевого призначення;

- інформація про в’їзд іноземних громадян в Україну за метою поїздок певною мірою деталізована і містить 7 рубрик (службова, ділова, дипломатична; туризм; приватна; навчання; працевлаштування; імміграція; культурний та спортивний обмін, релігійна, інша), хоча у змістовному плані ці рубрики частково перекриваються. На жаль, інформація про виїздгромадян України за кордон структурована лише за 3 рубриками (службова поїздка; організований туризм; приватна поїздка);

- оприлюднені на офіційному сайті Держстату України дані ДПСУ про перетин державного кордону іноземними громадянами і громадянами України за 2014 р. наведені без будь-яких коментарів щодо втрати контролю над частиною російської ділянки державного кордону України. Отже, зазначені особливості відомчої статистики ДПСУ ускладнюють структурний аналіз транскордонних потоків населення.

2. Пріоритетним завданням $є$ характеристика масштабів i динаміки транскордонного руху населення. Спочатку зупинимось на аналізі даних про прибуття іноземців до України (рис. 1). Швидкий висхідний тренд обсягів в'їного потоку іноземних громадян в Україну в 2006-2008 рр. можна пояснити зростанням інтересу в світі до нашої країни після бурхливих політичних подій 20042005 рр., а також встановленням у 2005 р. безвізового режиму в'їзду в Україну для громадян держав-членів ЄC, США, Канади, Японії, Швейцарії та ін. Після спаду внаслідок глобальної фінансово-економічної кризи 2008-2009 рр. позитивна тенденція зростання обсягів в’їзного потоку відновилася. Амплітуда значень між показниками 2008 і 2014 років становить 12,7 млн перетинів. Аномальним став показник 2014 р. - падіння обсягу на 48,5\% (!) порівняно 3 2013 р. Цей катастрофічний спад вимагає окремого коментаря 3 обов'язковим залученням даних про географічну структуру в’ізного потоку іноземних громадян в Україну, що буде зроблено трохи нижче.

Важливою характеристикою в’їзного потоку $€$ його структура за метою поїздки. Традиційно домінують дві головні причини прибуття іноземців в Україну: 1) приватна (близько $3 / 4$ усіх прибуттів); 2) культурний та спортивний обмін, релігійна, інша (близько 1/5 всіх прибуттів). За 2012-2014 рр. частка прибуттів 3 метою туризму скоротилась від 4,1 до $1,2 \%$, зі службовою, діловою та дипломатичною метою - від 1,5 до 0,4\%, що є для України тривожним сигналом. Частина іноземців вважає Україну «територією війни і злиднів».

Щорічно до України прибувають іноземні громадяни зі 115-130 держав світу (у тому числі громадяни майже 60 держав - у безвізовому режимі). Найбільші потоки до України генерують сусідні країни. Так, за період 2006-2013 рр. стабільними лідерами рейтингу були Росія, Молдова, Білорусь і Польща. Їх сукупна частка у загальній кількості іноземців, які відвідували Україну, становила близько 4/5 всіх прибуттів.

Абсолютні обсяги в’їзного потоку з Російської Федерації до України за період 2006-2013 рp. коливались в інтервалі від 6,4 млн (2006р.) до 10,3 млн (2013 р.). Частка Росії у загальній кількості прибуттів іноземних громадян до України традиційно є найбільшою і жодного року не падала нижче 30\%. Масштабні потоки людей між Росією та Україною - цілком природне явище, вони склалися під дією добре відомих чинників історичного, етнічного, економічного і соціокультурного характеру. Мільйони людей 3 обох країн $\epsilon$ близькими родичами, друзями, колегами. Агресивна політика Росії по відношенню до України, масована антиукраїнська пропаганда, анексія Криму, дозвіл Ради Федерації президенту Російської Федерації на використання Збройних сил на території України, збройний конфлікт на Донбасі, великі людські та матеріальні втрати стали шоком для українського суспільства. Україна втратила контроль над 409 км російської ділянки державного кордону. Світове співтовариство не визнає грубих порушень Росією норм між-народного права, підтримує незалежність, суверенітет i територіальну цілісність України у міжнародно визнаних кордонах.

Зупинимось детальніше на порівняльному аналізі рейтингів країн світу за їх часткою у загальному обсязі в'їзного потоку іноземних громадян до України за останні роки (табл. 1 на с. 14, зазначені країни з часткою не менше 1 відсотка).

Як вказувалось вище, у 2014 р. відбулось різке скорочення загального обсягу в'їзного потоку в Україну порівняно з 2013 р. (в абсолютному вимірі - майже на 12 млн перетинів менше). Кількість прибуттів з Росії зменшилась $з$ 10,3 до 2,4 млн (на 7,9 млн або у 4,3 рази). Тобто падіння загального обсягу в’ізного потоку в Україну на 2/3 пояснюється втратами в обміні саме з Росією. Традиційно частка Росії майже вдвічі перевищувала частку Молдови, та тепер вже Молдова опинилася на першому рядку рейтингу. Ситуація 3 транскордонними потоками громадян між Росією та Україною у 2014 р. змінилася кардинально. Результати спільного моніторингу громадської думки в обох країнах Київським міжнародним інститутом соціології і російською недержавною дослідницькою організацією «ЛевадаЦентр» вказують на суттєве погіршення ставлення населення Росії до України і населення України до Росії. 3 боку України 3 причин державної безпеки встановлювались обмеження на перетин кордону для громадян Росії чоловічої статі призовного віку. Росія згортає пасажирське сполучення з Україною.

Звертає на себе увагу помітне зростання у 2014 р. порівняно з 2013 р. часток прибуттів іноземців 
Таблиия 1

Географічна структура в’їзного потоку іноземних громадян в Україну за країнами, з яких вони прибули, у 2012-2014 pp. (\%)

\begin{tabular}{|c|c|c|}
\hline 2012 & 2013 & 2014 \\
\hline $\begin{array}{l}\text { 1. Росія - 41,4 } \\
\text { 2. Молдова - 21,1 } \\
\text { 3. Білорусь - } 13,4 \\
\text { 4. Польща - } 6,1 \\
\text { 5. Румунія - } 3,4 \\
\text { 6. Угорщина - } 3,2 \\
\text { 7. Словаччина - 2,1 } \\
\text { 8. Німеччина - 1,2 } \\
\text { 9. Інші країни - } 8,1\end{array}$ & $\begin{array}{l}\text { 1. Росія - 41,7 } \\
\text { 2. Молдова - } 22,0 \\
\text { 3. Білорусь - } 13,6 \\
\text { 4. Польща - 5,1 } \\
\text { 5. Румунія - 3,6 } \\
\text { 6. Угорщина - } 3,1 \\
\text { 7. Словаччина - } 1,7 \\
\text { 8. Німеччина - } 1,0 \\
\text { 9. Узбекистан - } 1,0 \\
\text { 10. Інші країни - } 7,2\end{array}$ & $\begin{array}{l}\text { 1. Молдова - } 34,4 \\
\text { 2. Росія - } 18,6 \\
\text { 3. Білорусь - } 12,5 \\
\text { 4. Польща - } 8,8 \\
\text { 5. Угорщина - } 6,9 \\
\text { 6. Румунія - } 4,6 \\
\text { 7. Словаччина - } 3,3 \\
\text { 8. Узбекистан - } 1,2 \\
\text { 9. Німеччина - } 1,0 \\
\text { 10. Інші країни - } 8,7\end{array}$ \\
\hline
\end{tabular}

Розраховано за даними Держприкордонслужби України [25]. Без обслуговуючого персоналу транспортних засобів та транзиту.

Таблиия 2

Географічна структура виїзного потоку громадян України за країнами, до яких вони виїжджали, у 2012-2014 pp. (\%)

\begin{tabular}{|c|c|c|}
\hline 2012 & 2013 & 2014 \\
\hline $\begin{array}{l}\text { 1. Росія - } 27,7 \\
\text { 2. Польща - } 26,9 \\
\text { 3. Молдова - 10,1 } \\
\text { 4. Угорщина - } 8,2 \\
\text { 5. Білорусь - } 7,8 \\
\text { 6. Туреччина - } 2,6 \\
\text { 7. Румунія - 2,6 } \\
\text { 8. Словаччина - 2,4 } \\
\text { 9. Німеччина - } 1,8 \\
\text { 10. Чехія - } 1,4 \\
\text { 11. Сгипет - } 1,4 \\
\text { 12. Інші країни - } 7,1\end{array}$ & $\begin{array}{l}\text { 1. Польща - 29,4 } \\
\text { 2. Росія - 25,9 } \\
\text { 3. Молдова - 10,1 } \\
\text { 4. Угорщина - } 8,0 \\
\text { 5. Білорусь - 7,3 } \\
\text { 6. Румунія - 3,3 } \\
\text { 7. Туреччина - } 2,4 \\
\text { 8. Словаччина - } 2,4 \\
\text { 9. Німеччина - } 1,6 \\
\text { 10. Єгипет - 1,4 } \\
\text { 11. Інші країни - } 8,2\end{array}$ & $\begin{array}{l}\text { 1. Польща - 34,1 } \\
\text { 2. Росія - 20,8 } \\
\text { 3. Молдова - 10,8 } \\
\text { 4. Угорщина - 9,6 } \\
\text { 5. Білорусь - } 6,9 \\
\text { 6. Словаччина - 2,9 } \\
\text { 7. Румунія - 2,3 } \\
\text { 8. Туреччина - 2,0 } \\
\text { 9. Єгипет - } 1,8 \\
\text { 10. Німеччина - 1,4 } \\
\text { 11. Інші країни - 7,4 }\end{array}$ \\
\hline
\end{tabular}

Розраховано за даними Держприкордонслужби України [24]. Без обслуговуючого персоналу транспортних засобів та військовослужбовців.

Частка окремих ділянок державного кордону України

Таблиия 3.

у пропуску фізичних осіб (на в'їзд та виїзд разом, \%)

\begin{tabular}{|l|r|r|r|r|r|r|}
\hline Ділянки державного кордону & $\mathbf{2 0 0 0}$ & $\mathbf{2 0 0 5}$ & $\mathbf{2 0 1 0}$ & $\mathbf{2 0 1 1}$ & $\mathbf{2 0 1 2}$ & \multicolumn{1}{|c|}{$\mathbf{2 0 1 3}$} \\
\hline $\begin{array}{r}\text { Разом перетинів усіма } \\
\text { особами }\end{array}$ & 100,00 & 100,00 & 100,00 & 100,00 & 100,00 & 100,00 \\
$\begin{array}{r}\text { д т.ч. за } \\
\text { ділянками кордону }\end{array}$ & & & & & & \\
\hline польська & 18,84 & 21,66 & 15,57 & 16,13 & 16,44 & 17,23 \\
\hline словацька & 2,20 & 2,63 & 2,43 & 2,30 & 2,11 & 2,10 \\
\hline угорська & 5,60 & 10,03 & 6,99 & 6,31 & 5,89 & 6,01 \\
\hline румунська & 1,31 & 1,28 & 3,61 & 3,11 & 3,06 & 3,23 \\
\hline молдовська & 16,96 & 12,88 & 17,27 & 17,13 & 16,15 & 15,99 \\
\hline російська & 37,34 & 34,02 & 31,63 & 32,09 & 31,95 & 30,66 \\
\hline білоруська & 11,42 & 9,75 & 11,68 & 10,93 & 11,57 & 11,69 \\
\hline морська & 1,97 & 1,06 & 0,87 & 0,74 & 0,69 & 0,68 \\
\hline повітряна & 4,36 & 6,69 & 9,95 & 11,26 & 12,14 & 12,41 \\
\hline
\end{tabular}

Розраховано за даними Держприкордонслужби України [22] 
3 Молдови (+ 12,4 п.п.), Угорщини (+ 3,8 п.п.), Польщі (+ 3,7 п.п.), Словаччини (+ 1,6 п.п.).

Розглянемо тепер обсяги, причини та географічну структуру виїзного потоку. Обсяги виїзду громадян України за кордон теж зазнали впливу світової фінансово-економічної кризи 2008-2009 рр., а потім динамічно зростали. Амплітуда значень між показниками 2009 і 2013 років становить 8,5 млн перетинів. Вона суттєво поступається розмаху варіації значень в’їзного потоку. Гостра і глибока суспільно-політична криза 2013-2014 рр. стала додатковим генератором транскордонного руху населення. Саме ці роки характеризуються найбільшими обсягами виїзного потоку, до того ж вельми вірогідною $є$ неповнота офіційних даних за 2014 р. За приблизними оцінками Управління Верховного комісара $\mathrm{OOH}$ у справах біженців, бойові дії на сході України станом на березень 2015 р. призвели до виникнення потоків внутрішньо переміщених осіб чисельністю 1,1 млн, а також 674,3 тис. біженців та осіб, бажаючих отримати легальний статус на території сусідніх держав (у тому числі 542,8 тис. в Росії, 80,7 тис. в Білорусі).

Аналіз даних ДПСУ щодо мети поїздки свідчить скоріше про неможливість встановити за ними справжні причини перетину кордону. Частка громадян України, які виїжджали за кордон 3 приватною метою, зросла від 87,5 \% у 2010 р. до 98,3\% у 2014 р. Необхідні інші методичні інструменти, здатні виявити справжню роль економічних мотивів, туризму тощо. Де-факто у виїзному потоці присутні особи, які перетинають кордон 3 метою роботи за наймом, ведення бізнесу, навчання, лікування, здійснення покупок, відвідування друзів або родичів, пошуку притулку, біженці тощо.

Важливим індикатором, що вказує на колосальну економічну роль тимчасової та довгострокової трудової міграції для країни та і1і масштаби, є приватні грошові перекази до України. За даними Національного банку України, у 2013 р. через банки, міжнародні платіжні системи і неформальні канали із-за кордону було перераховано 8,5, за 2014 р. - 6,5 млрд дол. США. Найбільші валютні надходження від українських заробітчан з Росії, США, Німеччини, Греції, Кіпру тощо. Для порівняння додамо, що обсяги прямих іноземних інвестицій в Україну за 2013 і 2014 роки становили відповідно 5,7 і 2,5 млрд дол. США.

Громадяни України щорічно відвідують близько 100 країн світу. На початок 2015 р. безвізовий режим 3 Україною встановили 42 держави, ще 52 дозволяють отримати візи при в’їзді на кордоні. Традиційно наші співвітчизники найчастіше відвідують Росію, Польщу, Молдову, Угорщину і Білорусь. Якщо 2010 р. до Росії прямували 30,5 \% громадян України, які виїжджали за кордон, то 2014 р. - лише 20,8\%. Кількість громадян України, які виїжджали до Росії, зменшилась за 2013-2014 рр. 3 6,1 до 4,7 млн осіб (на 1,4 млн або на 23 \%). Це дозволяє зробити висновок про важливість російського ринку праці для громадян України. Останнім часом позиції окремих країн у рейтингах змінилися (табл. 2, зазначені країни
3 часткою не менше 1 відсотка). Вже два роки поспіль на першому місці опиняється Польща. Підкреслимо також помітні позиції популярних туристичних дестинацій - Туреччини та Сгипту.

3. Наступним етапом роботи була оцінка ролі окремих ділянок державного кордону України у забезпеченні руху фізичних осіб. На даному етапі в'їзний i виїзний потоки іноземців і громадян України розглядалися разом i розподілялися між окремими ділянками кордону. Іншими словами, ділянки кордону виступають своєрідними каналами пропуску потоків населення. Яким же чином потоки людей розподіляються між ділянками державного кордону? Для відповіді на це питання проаналізуємо табл. 3.

На момент підготовки статті до друку ще не вся статистична інформація за 2014 р. була оприлюднена. Проте навіть без урахування даних 2014 р. табл. 3 дозволяє зробити певні узагальнення. Ключову роль у забезпеченні транскордонного руху населення між Україною і рештою світу відіграють сухопутні ділянки кордону 3 сусідніми державами пострадянського простору: Росією, Білоруссю і Молдовою. Хоча їх сукупна частка і скорочується, але залишається найбільшою (2000 p. - 65,7\%, 2010 p. - 60,6\%, 2013 р. - 58,3\%). За підсумками 2014 р. варто очікувати на прискорення цього скорочення. Сукупна частка польської, словацької, угорської та румунської ділянок кордону $є$ вдвічі меншою, проте послідовна реалізація Угоди про асоціацію між Україною та Європейським Союзом призведе до інтенсифікації руху населення через західний кордон.

Морська ділянка кордону не відіграє суттєвого значення у забезпеченні міждержавного руху населення. Завдяки стійкому зростанню обсягів перевезень пасажирів авіаційним транспортом у міжнародному сполученні спостерігалася тенденція до посилення ролі повітряного простору. В 2014 р. внаслідок військових загроз безпеці держави i польотів цивільної авіації, фактичної втрати кількох аеропортів, падіння внутрішнього попиту через погіршення рівня життя населення України обсяги перевезень пасажирів у міжнародному сполученні зменшились на 16\%. Неминучим є зменшення ролі повітряної ділянки державного кордону за підсумками 2014-2015 pp.

Висновки і перспективи подальших розвідок. Отже, в сучасних умовах зростає актуальність широкого трактування міграції як просторової мобільності населення. Головним джерелом інформації про потоки громадян України та іноземних громадян через державний кордон є статистика Державної прикордонної служби України. Дані ДПСУ лише умовно можуть вважатися статистикою транскордонних потоків населення, вони не завжди відповідають міжнародним рекомендаціям. Бажано обліковувати не тільки факти перетину кордону, але й кількість фізичних осіб. Під час пропуску в Україну іноземного громадянина доцільно фіксувати країну, з якої він прибув, а також громадянство цієї особи. Під час виїзду громадянина 
України за кордон необхідно зазначати країну кінцевого призначення і деталізувати мету подорожі. Це дозволить удосконалити структурний аналіз транскордонних потоків населення.

Позитивна тенденція зростання обсягів в’їзного потоку іноземних громадян в Україну за 2009-2013 pр. змінилася різкім спадом за підсумками 2014 р. На 2/3 це пояснюється втратами в обміні з Росією. Лідером рейтингу країн світу за їх часткою у загальному обсязі в’їзного потоку іноземних громадян до України вперше стала Молдова, Росія - друга, зміцнили свої позиції Угорщина, Польща, Словаччина, Румунія.

Гостра і глибока криза 2013-2014 рр. в Україні стала додатковим генератором просторового руху населення, з'явилися нові категорії вимушених мігрантів. Ці роки характеризуються найбільшими обсягами виїзногопотокугромадян України за кордон, до того ж вельми вірогідною є неповнота офіційних даних за 2014 р. Традиційно наші співвітчизники найчастіше відвідують Росію, Польщу, Молдову, Угорщину i Білорусь. Відбулася зміна лідера в структурі виїзного потоку: вже два роки поспіль на першому місці опиняється Польща, Росія - друга.

Транскордонна взаємодія України 3 іншими державами, пов'язана з потоками фізичних осіб, характеризується зміною структурних пропорцій. Сукупна частка ділянок кордону України з сусідніми державами пострадянського простору скорочується, а з країнами $\mathrm{CC}$ - зростає. В найближчій перспективі варто очікувати зменшення ролі повітряної ділянки державного кордону у пропуску іноземних громадян і громадян України на в’їзд та виїзд.

Жанр наукової статті обумовив розкриття лише окремих аспектів складної і важливої для сучасної України проблеми транскордонного руху населення. В перспективі варто зосередити увагу на дослідженні:

- взаємозв'язків між загрозами національній безпеці держави і розвитком транскордонних потоків населення, їх масштабами і конфігурацією;

- потоків населення через кордон між парами країн (наприклад, Україна - Польща) із застосуванням такого методичного інструменту як «дзеркальна статистика»;

- впливу туризму на обсяги і географію транскордонних потоків населення;

- ролі пасажирського транспорту як чинника розвитку міжнародних міграційних потоків тощо.

\section{References:}

1. Balabanov G. V. Teritorìal'na struktura zovnìsnìh turističnih potokìv Ukraïni [Territorial structure of foreign tourist flows in Ukraine]. Turizm i gostinnist'v Ukrä̈ni: stan, problemi, perspektivi rozvitku [Tourism and hospitality in Ukraine: state, problems, prospects of development]. - Cherkasy, 2012, pp. 146-153 (In Ukrainian).

2. Dûvel' F. Prostranstvennaâ mobil'nost' naseleniâ: indikatory, kategorii i tipologii [Spatial population mobility: indicators, categories and typologies]. Metodologiâ i metody izučeniâ migracionnyh processov [Methodology and methods of studying migration processes], Moscow, 2007, pp. 71-95 (In Russian).

3. Faŝevskij N. I., Rudenko L. G., Nemčenko M. P., Misevič K. N. Mežgosudarstvennye migracionnye svâzi Ukrainy: osnovnye tendencii i problemy [Interstate migration in Ukraine: main trends and challenges]. Ukraïns'kij geografičnij žurnal [Ukrainian geographical journal], 2007, Vol. 4, pp. 33-38. (In Russian).

4. Faŝevskij N. I., Rudenko L. G., Nemčenko M. P., Misevič K. N. Problemy mežgosudarstvennyh migracionnyh svâzej Ukrainy i osnovnye puti ih rešeniâ [Problems of interstate migration in Ukraine and ways of their solutions]. Ukraïns'kij geografičnij žurnal [Ukrainian geographical journal], 2007, Vol. 3, pp. 35-39. (In Russian).

5. Gumenûk Û. P. Mižnarodna trudova migracîa: metodologičnij ta organizacìnij aspekti: monografîa [International labor migration: methodological and organizational aspects: Monograph], Ternopil, 2013 , 618 p. (In Ukrainian).

6. International Migration Law: Glossary on Migration. Geneva, 2004, 81 p. Access mode: http://publications. iom.int/bookstore/free/IML_1_EN.pdf.

7. International migration statistics: practical guide for Eastern Europe and Central Asia, 2011, 104 p. Access mode: http://www.unece.org/fileadmin/DAM/stats/publications/RUS_International_Migration_Statistics_Practical_ Guide.pdf. (In Russian).

8. Malinovs'ka O. Ukraïna, Êvropa, mìgracîâ: mìgracï naselennâ Ukrä̈ni v umovah rozširennâ ÊS [Ukraine, Europe, migration: migration of Ukrainian population in terms of EU enlargement]. Kyiv, 2004 , 172 p. (In Ukrainian).

9. Malinovs'ka O. A. Urìznomanitnennâ skladu naselennâ Ukrä̈ni pìd vplivom mižnarodnö̈ migracï: viklik ta šlâhi reaguvannâ: analitična dopovid' [Diversifying of Ukrainian population composition under the influence of international migration: a challenge and ways to respond: analytical report]. Kyiv, 2012, 51 p. (In Ukrainian).

10. Migracìna statistika v Ukraïnì ta šlâhi ï udoskonalennâ: analitična zapiska [The migration statistics in Ukraine: ways of improving: analytical report]. Access mode: http://www.niss.gov.ua/articles/1694/. (In Ukrainian).

11. Migracijni procesi v Ukraïni: sučasnij stan i perspektivi: monografiâ [Migration in Ukraine: current state and prospects: monograph] (Ed.: Poznâk O.V.). Uman', 2007, 276 p. (In Ukrainian).

12. Migracijnij profil' Ukraïni 2010-2013 [Ukraine migration profile, 2010-2013]. Access mode: http://dmsu.gov. ua/images/files/UKR Migration \%20 Profile 2013.pdf. (In Ukrainian).

13. Naselennâ Uǩrä̈ni za $20 \overline{1} 3$ rikk: demografičnij ŝroričnik [Ukrainian Population, 2013: Demographic Yearbook]. Kyiv, 2014, 295 p. Access mode: http://www.ukrstat.gov.ua. (In Ukrainian).

14. Poznâk O. V. Social'nì naslidki êvroìntegracï Ukraïni. Mižnarodna mìgraciâ [The social consequences of 
Ukraine's European integration. International migration]. Kyiv, 2012, 20 p. (In Ukrainian).

15. Problemi rozvitku transkordonnogo spivrobitnictva Ukraïni v umovah rozširenogo ÊS : monografiâ [Problems of cross-border cooperation in Ukraine in terms of EU enlargement : monograph]. (Ed.: N. Mikula, V. Borŝevs'kij, T. Vasil'cìv). L'viv, 2009, 436 p. (In Ukrainian).

16. Regulation (EC) No 862/2007 of the European Parliament and of the Council of 11 July 2007 on Community statistic son migration and international protection and repealing Council Regulation (EEC) No 311/76 on the compilation of statistic son foreign workers. Access mode: http:/eurex.europa.eu/legalcontent/EN/ALL/;jsessionid $=\mathrm{c}$ Dj9TCcFLgT0q7TLBTTYpFlqYvGJJh4RBdjhrGFLlmn3Nxhn2WzM!1967577200?uri=CELEX:32007R0862.

17. Rekomendacii po statistike meždunarodnoj migracii. 1-e peresmotrennoe izdanie [Recommendations on statistics of international migration: 1st revised edition]. New York, 1998, 128 pp. Access mode: http://unstats.un.org/ unsd/publication/SeriesM/SeriesM_58rev1R.pdf. (In Russian).

18. Rudenko L. G., Faŝevskij N. I., Nemčenko M. P., Misevič K. N. Social'no-èkonomičeskoe razvitie regionov Ukrainy i mežgosudarstvennaâ migraciâ naseleniâ [The social and economic development of Ukraine's regions and the interstate migration]. Ukrä̈ns'kij geografičnij žurnal [Ukrainian geographical journal], 2007, Vol. 4, pp. 44-50 (In Russian).

19. Rybakovskij L. L. Migraciâ naseleniâ (voprosy teorii) [The migration of population (theoretical issues)]. Moscow, 2003, 238 p. (In Russian).

20. Spravočnik po terminologii v oblasti migracii (russko-anglijskij) [Handbook on migration terminology (Russian-English)].Moscow, 2011, 166 pp. Access mode: http://moscow.iom.int/publications/Handbook_on_Migration_ Terminology.pdf. (In Russian).

21. Transformacia migracionnyh processov na postsovetskom prostranstve [The transformation of migration processes in the former Soviet Union]. (Ed.: L. L. Rybakovskij). Moscow, 2008, 488 p. (In Ukrainian).

22. Transport ì zv'âzok Ukrä̈n - 2013. Statističnij zbirnik [Transport and communications in Ukraine - 2013. Statistical Yearbook]. Kyiv, 2014, 221 p. Access mode: http://www.ukrstat.gov.ua/. (In Ukrainian).

23. Vìdâkìna M. M., Stakanov R. D. Trudova migraciâ z Ukrä̈ni do ÊS: makroekonomičnij vimìr: monografîa [Vidjakina M. M. Labor migration from Ukraine to the EU: macroeconomic dimension: monograph]. Kyiv, 2011, 198 p. (In Ukrainian).

24. Viïzd gromadân Ukraïni za kordon za kraïnami, do âkih voni viiždžali, u 2014 rocì [The departure of Ukrainian citizens abroad by countries which they visited, 2014] Access mode: http://www.ukrstat.gov.ua/operativ/operativ2012/ tyr/tyr_u/vigw2014_u.htm. (In Ukrainian).

25. V'izd inozemnih gromadân v Ukraïnu za kraïnami, z âkih voni pribuli, u 2014 rocì [The entry of foreign citizens in Ukraine by countries from which they came, 2014]. Access mode: http://www.ukrstat.gov.ua/operativ/ operativ2013/tyr/tyr_u/vig2014_u.htm. (In Ukrainian). 